Article

\title{
Continuous Production of 2-Phenylethyl Acetate in a Solvent-Free System Using a Packed-Bed Reactor with Novozym ${ }^{\circledR} 435$
}

\author{
Shang-Ming Huang ${ }^{1}$, Hsin-Yi Huang ${ }^{1}$, Yu-Min Chen ${ }^{1}$, Chia-Hung Kuo ${ }^{2, *} \mathbb{D}$ and \\ Chwen-Jen Shieh ${ }^{1 \text {,* }}$ \\ 1 Biotechnology Center, National Chung Hsing University, Taichung 402, Taiwan; \\ zxzxmj2323@hotmail.com (S.-M.H.); hyhuang8273@dragon.nchu.edu.tw (H.-Y.H.); \\ sunnycg710@gmail.com (Y.-M.C.) \\ 2 Department of Seafood Science, National Kaohsiung University of Science and Technology, \\ Kaohsiung 811, Taiwan \\ * Correspondence: kuoch@nkust.edu.tw (C.-H.K.); cjshieh@nchu.edu.tw (C.-J.S.); \\ Tel.: +886+7+361-7141 (ext. 23646) (C.-H.K.); +886+4+2284-0450 (ext. 5121) (C.-J.S.)
}

Received: 1 June 2020; Accepted: 24 June 2020; Published: 26 June 2020

check for updates

\begin{abstract}
Phenylethyl acetate (2-PEAc), a highly valued natural volatile ester, with a rose-like odor, is widely added in cosmetics, soaps, foods, and drinks to strengthen scent or flavour. Nowadays, 2-PEAc are commonly produced by chemical synthesis or extraction. Alternatively, biocatalysis is a potential method to replace chemical synthesis or extraction for the production of natural flavour. Continuous synthesis of 2-PEAc in a solvent-free system using a packed bed bioreactor through immobilized lipase-catalyzed transesterification of ethyl acetate (EA) with 2-phenethyl alcohol was studied. A Box-Behnken experimental design with three-level-three-factor, including 2-phenethyl alcohol (2-PE) concentration (100-500 mM), flow rate $\left(1-5 \mathrm{~mL} \mathrm{~min}^{-1}\right)$ and reaction temperature $\left(45-65^{\circ} \mathrm{C}\right)$, was selected to investigate their influence on the molar conversion of 2-PEAc. Then, response surface methodology and ridge max analysis were used to discuss in detail the optimal reaction conditions for the synthesis of 2-PEAc. The results indicated both 2-PE concentration and flow rate are significant factors in the molar conversion of 2-PEAc. Based on the ridge max analysis, the maximum molar conversion was $99.01 \pm 0.09 \%$ under optimal conditions at a 2-PE concentration of $62.07 \mathrm{mM}$, a flow rate of $2.75 \mathrm{~mL} \mathrm{~min}^{-1}$, and a temperature of $54.03{ }^{\circ} \mathrm{C}$, respectively. The continuous packed bed bioreactor showed good stability for 2-PEAc production, enabling operation for at least $72 \mathrm{~h}$ without a significant decrease of conversion.
\end{abstract}

Keywords: Lipase; transesterification; 2-phenylethyl acetate; packed-bed reactor; solvent-free; ethyl acetate

\section{Introduction}

Floral scent is an important ingredient to enhance flavor, and its main component is esters. They are commonly applied to many products, such as perfume, cosmetics, natural food additives, pharmaceuticals, and even in oral use [1]. Among aromatic compounds, 2-phenylethyl acetate (2-PEAc) is one of the most important chemicals of flower fragrance [2,3]. 2-PEAc, $\mathrm{C}_{10} \mathrm{H}_{12} \mathrm{O}_{2}$, is a transparent, colorless oily liquid with the fragrance of rose and honey. A rose emission scent is mainly contributed by 2-PEAc, cis-3-hexenyl acetate, geranyl acetate, and citronellyl acetate when a rose flower has opened $[4,5]$. Nowadays, 2-PEAc is also widely used in the blending of flower and fruit flavors, belonging to a food additive [6]. In the traditional method for preparing 2-PEAc, although it can be extracted from plants or chemically synthesized, the concentration of 2-PEAc aromatic esters extracted by this conventional method is low, the extraction process is complicated, and the cost is high [7]. Essential oils extracted 
from plants require a large number of raw materials. Moreover, the extraction process is complicated because there are always many factors that affect the yield [8]. Since the extraction method of aromatic compounds is more expensive and the yield is low, the chemical synthesis becomes the main source of 2-PEAc. The chemical method is usually through acetylation of 2-phenethyl alcohol (2-PE) or esterification of 2-PE with acetic acid to obtain 2-PEAc [8,9]. However, chemical synthesis has disadvantages such as non-specific reactions, long reaction times, many byproducts, environmental pollution, and so on [10]. In recent years, the alternative methods for producing natural aromatic esters by microbial fermentation or metabolic engineering were studied [11-14]. Although microbial fermentation had a high transform rate, it was challenging to separate and recover the 2-PEAc from fermentation broth.

Biocatalysis applied in ester synthesis is useful and its synthesized product can be identical to the natural product. Biocatalysis offers several advantages, such as high specificity, selectivity, low energy consumption, and high yield [15-17]. Currently, an esterification or transesterification reaction catalyzed by lipase (triacylglycerol ester hydrolase, EC 3.1.1.3) in the organic solvent has been performed to produce esters $[18,19]$. Lipase-catalyzed reactions have been applied to the synthesis of emulsifiers [20], wax esters [21], structural lipids [22], and biodiesel [23]. Enzymatic catalysis is performed under moderate reaction conditions $(\mathrm{pH}$, temperature, and atmospheric pressure), and the substrate is more specific for producing high-quality natural products [24]. Regarding industrial development, immobilized biocatalysts are favored because of their convenience for separation, recycling, and reuse. Recently, the immobilization of lipase on hydrophobic supports has shown hyper-activation activity $[25,26]$. However, when the substrate is very large or hydrophilic, lipase-catalyzed ester synthesis may cause steric hindrance, thereby reducing lipase activity [27].

Solvent, as the name suggests, can dissolve the reactants to form a uniform reaction system; the solvent can adjust the concentration and temperature of the reactants to control the rate and direction of the chemical reaction; the solvent can also be used to extract and separate specific compounds. Therefore, in traditional chemical reactions, the choice of solvent is often an important issue. However, solvents, especially organic solvents, are the main source of environmental pollution. As humanity's environmental awareness is increasingly awakened, green chemistry has gradually formed a new scientific philosophy. A solvent-free system for lipase-catalyzed reaction employing a reactant as the solvent is a simple mixture of reactants. Solvent-free systems present advantages, such as offering greater safety, reduction in solvent extraction costs, increased reactant concentrations, consequently volume productivity, and being friendly to the environment [28]. To date, the solvent-free system has been developed successfully for the synthesis of many esters, such as octyl ferulate [29], octyl hydroxyphenylpropionate [30], caffeic acid phenethyl ester [31], ethyl valerate (green apple flavour) and hexyl acetate (pear flavour) [32]. So far, the use of solvent-free systems for enzymatic synthesis of 2-PEAc has not been reported. Ethyl acetate (EA) has been used as reactant for synthesis of DHA/EPA (Omega-3 fatty acids) ethyl ester [33]. Therefore, we choose EA as a reactant, it also acts as a solvent in the lipase-catalyzed synthesis of 2-PEAc.

A fixed bed reactor is also called a packed bed reactor, and it is filled with a solid catalyst or solid reactants to achieve a multi-phase reaction. The solids are usually in the form of particles, stacked into a bed of a certain height (or thickness), the bed is stationary, and the fluid reacts through the bed. A packed bed reactor has low mechanical wear on the catalyst. The flow of the fluid in the bed is close to the plug flow result in using a smaller amount of catalyst and a smaller reactor volume can obtain a larger production capacity. Since the residence time can be strictly controlled and the temperature distribution can be adjusted appropriately, it is particularly beneficial for achieving high selectivity and conversion. The packed bed reactor using immobilized enzyme has been used for the production of galactooligosaccharides [34], high fructose syrup [35], hexyl laurate [25], and geraniol esters [36]. Four types of bioreactor, namely (1) stirred-tank, (2) packed-bed, (3) membrane, and (4) fluidized-bed, are currently used in the bio-, chemical, and food industry. Small-scale factories usually use batch reactors, but factories with large annual output must use continuous reactors, which is more economical. Commercially, they are best used continuously to minimize labor and overhead costs. 
Therefore, this study applies the advantages of the solvent-free system and designs of packed bed reactors with immobilized lipase for the synthesis of 2-PEAc.

In this study, a green strategy for synthesis of 2-PEAc by transesterification of ethyl acetate with 2-phenyl alcohol catalyzed by lipase was studied. The 2-PEAc was synthesized using Novozym ${ }^{\circledR} 435$ in a packed-bed reactor with a solvent-free system, the reaction parameters affecting the synthesis of 2-PEAc were evaluated, and the response surface methodology (RSM) using a three-level-three-factor Box-Behnken design was conducted to determine the optimal condition of 2-phenethyl alcohol (2-PE) concentration, mixture flow rate and reaction temperature on molar conversion of 2-PEAc.

\section{Results and Discussion}

\subsection{Prime Experiment}

The enzyme-catalyzed reaction in a solvent-free system simply mixes the reactants to carry out the enzyme-catalyzed reaction without the organic solvent [37]. It possesses some advantages of organic phase enzyme-catalyzed reactions, such as the reaction thermodynamic balance moving from hydrolysis to synthesis, and the enzyme has a high degree of stability. It also overcomes the shortcomings of the high toxicity of organic solvents, flammability and volatility, emitting pollution to the environment, and the high cost of recovery and recycling. At the same time, the solvent-free synthesis provides a new molecular environment different from the traditional solvent for the reaction. In the solvent-free system, the enzyme directly acts on the substrate, which improves the substrate and product concentration and the reaction selectivity. The purification process is easy with fewer steps. Solvent-free system biosynthesis is more suitable for the development of the food industry because of its obvious advantages such as mild reaction conditions, high substrate concentration, and high reaction rate. Initially, the synthesis efficiency of 2-PEAc was investigated at a flow rate in the range of 1 to $5 \mathrm{~mL} \mathrm{~min}^{-1}$. Figure 1 shows the lipase-catalyzed synthesis of 2-PEAc from 2-PE and EA by transesterification. The reaction was carried out in a continuous packed bed reactor at $50{ }^{\circ} \mathrm{C}$ in a solvent-free system containing $100 \mathrm{mM}$ 2-PE (dissolved in EA) and $1 \mathrm{~g}$ immobilized enzyme. Figure 2 shows that at the flow rate of $1 \mathrm{~mL} \mathrm{~min}^{-1}, 3 \mathrm{~mL} \mathrm{~min}^{-1}$, and $5 \mathrm{~mL} \mathrm{~min}^{-1}$, the conversion rates of 2-PEAc after reaction for $2 \mathrm{~min}$ reached $100 \%, 95 \%$, and $80 \%$, respectively. The molar conversion increased by decreasing the flow rate. However, the conversion rate reached $100 \%$ and was almost unchanged

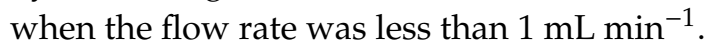

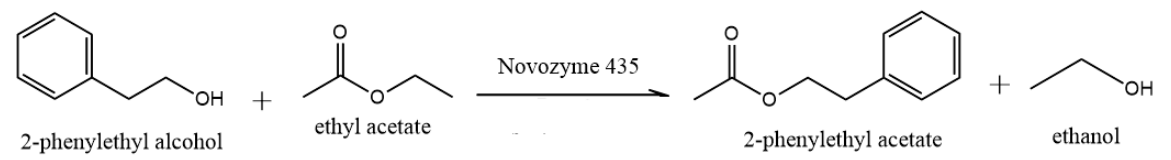

Figure 1. The reaction diagram of 2-phenylethyl acetate (2-PEAc) synthesis catalyzed by Novozym ${ }^{\circledR} 435$.

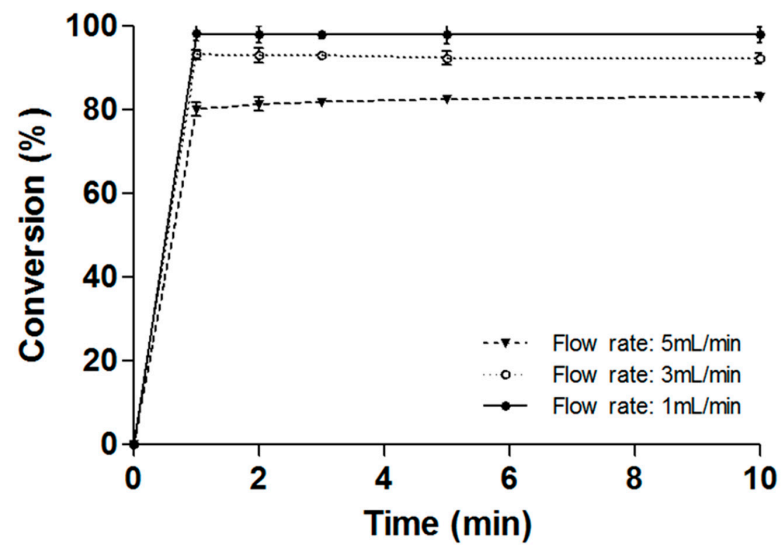

Figure 2. Effect of flow rate on the lipase-catalyzed synthesis of 2-PEAc in a packed-bed reactor at a substrate concentration of $100 \mathrm{mM}$ 2-phenethyl alcohol (2-PE) and temperature of $55^{\circ} \mathrm{C}$. 


\subsection{Model Fitting}

The major objective of this study was to develop and evaluate a statistical approach to better understand the relationship between variables and lipase-catalyzed transesterification reactions in solvent-free systems. According to the prime experimental result, the actual yields of 2-PEAc and the selected variables, including reaction temperature $50-70{ }^{\circ} \mathrm{C}, 2-\mathrm{PE}$ concentration of $100-500 \mathrm{mM}$, and flow rate of $1-5 \mathrm{~mL} \mathrm{~min}^{-1}$, are shown in Table 1 . The RSREG program of SAS was employed to fit the second-order polynomial equation (Equation (1)) to the experimental data. Among the various treatments, the highest molar conversion $98.66 \%$ was obtained by treatment 10 with a substrate concentration of $100 \mathrm{mM} 2-\mathrm{PE}$, a flow rate of $1 \mathrm{~mL} \mathrm{~min}^{-1}$, and a reaction temperature of $55^{\circ} \mathrm{C}$. In contrast, the lowest molar conversion $62.05 \%$ was obtained by treatment 6 with a substrate concentration of 500 $\mathrm{mM} 2-\mathrm{PE}$, a flow rate of $5 \mathrm{~mL} \mathrm{~min}{ }^{-1}$, and a reaction temperature of $55^{\circ} \mathrm{C}$. The second-order polynomial equation obtained was shown as follows:

$$
\begin{gathered}
\mathrm{Y}(\%)=84.53616-0.035396 \mathrm{X}_{1}+1.83595 \mathrm{X}_{2}+0.64601 \mathrm{X}_{3}-0.015505 \mathrm{X}_{1} \mathrm{X}_{2}+0.000830699 \mathrm{X}_{1} \mathrm{X}_{3} \\
+0.032430 \mathrm{X}_{2} \mathrm{X}_{3}-0.0000213020 \mathrm{X}_{1}^{2}-0.54497 \mathrm{X}_{2}^{2}-0.00781849 \mathrm{X}_{3}^{2}
\end{gathered}
$$

where $X_{1}$ is the concentration of 2-PE $(100-500 \mathrm{mM}), X_{2}$ is the flow rate $\left(1-5 \mathrm{~mL} \mathrm{~min}^{-1}\right)$, and $X_{3}$ is the reaction temperature $\left(50-70{ }^{\circ} \mathrm{C}\right)$.

Table 1. Three-level-three-factor Box-Behnken design and the experiment data for response surface analysis.

\begin{tabular}{ccccc}
\hline \multirow{2}{*}{$\begin{array}{c}\text { Treatment } \\
\text { No. }\end{array}$} & \multicolumn{4}{c}{ Factor } \\
\cline { 2 - 4 } & $\begin{array}{c}\mathbf{X}_{\mathbf{1}} \\
\text { Concentration of } \\
\text { 2-PE (mM) }\end{array}$ & $\begin{array}{c}\mathbf{X}_{\mathbf{2}} \\
\text { Flow Rate } \\
\left(\mathbf{m L ~ m i n}^{-1}\right)\end{array}$ & $\begin{array}{c}\mathbf{X}_{\mathbf{3}} \\
\text { Observed Molar } \\
\text { Conversion (\%) }\end{array}$ & \\
\hline 1 & $0(300)$ & $1(5)$ & $-1(45)$ & $76.53 \pm 1.70$ \\
2 & $1(500)$ & $0(3)$ & $-1(45)$ & $74.58 \pm 1.62$ \\
3 & $-1(100)$ & $0(3)$ & $-1(45)$ & $97.30 \pm 0.41$ \\
4 & $0(300)$ & $-1(1)$ & $-1(45)$ & $95.44 \pm 0.80$ \\
5 & $-1(100)$ & $1(5)$ & $0(55)$ & $94.26 \pm 0.95$ \\
6 & $1(500)$ & $1(5)$ & $0(55)$ & $62.05 \pm 1.01$ \\
7 & $0(300)$ & $0(3)$ & $0(55)$ & $90.03 \pm 1.80$ \\
8 & $0(300)$ & $0(3)$ & $0(55)$ & $89.50 \pm 1.99$ \\
9 & $0(300)$ & $0(3)$ & $0(55)$ & $89.23 \pm 2.07$ \\
10 & $-1(100)$ & $-1(1)$ & $0(55)$ & $98.66 \pm 0.01$ \\
11 & $1(500)$ & $-1(1)$ & $0(55)$ & $91.25 \pm 0.33$ \\
12 & $0(300)$ & $1(5)$ & $1(65)$ & $79.10 \pm 1.22$ \\
13 & $1(500)$ & $0(3)$ & $1(65)$ & $81.93 \pm 1.86$ \\
14 & $-1(100)$ & $0(3)$ & $1(65)$ & $98.00 \pm 0.32$ \\
15 & $0(300)$ & $-1(1)$ & $1(65)$ & $95.42 \pm 0.16$ \\
\hline
\end{tabular}

${ }^{a}$ The treatments were run in a random order.

Analysis of variance (ANOVA) data (Table 2) shows that the second-order polynomial model can represent well the actual relationship between response and significant variables $\left(R^{2}=0.9971\right.$ and $p<0.0001)$. In contrast, the ANOVA results of responses revealed that there was no significant fit as $p>0.05$. Therefore, this model was adequate to predict the synthesis yields of 2-PEAc within the range of variables employed. Furthermore, Figure 3 shows that a highly linear relationship between predicted and experimental variables on molar conversion was obtained in this study. The actual 15 experimental results of molar conversion were similar to the prediction of the second-order polynomial equation. The effects of the three variables on molar conversion were analyzed by a joint test (Table 3 ). The results indicated that all three variables had significant effects on molar conversion $(p<0.05)$. Among them, the concentration of 2-PE $\left(X_{1}\right)$ and flow rate $\left(X_{2}\right)$ were more important variables toward molar conversion $(p<0.001)$ in this study. 
Table 2. Analysis of variance (ANOVA) analysis for continuous lipase-catalyzed 2-PEAc synthesis.

\begin{tabular}{cccc}
\hline Factors & Degree of Freedom & Sum of Squares & Prob $>$ F \\
\hline Linear & 3 & 1374.688873 & $<0.0001$ \\
Quadratic & 3 & 20.478243 & 0.0267 \\
Cross product & 3 & 166.589386 & 0.0002 \\
Total Model & 9 & 1561.756502 & $<0.0001$ \\
Lack of fit & 3 & & 0.1088 \\
Pure error & 2 & 4.206608 & \\
Total error & 5 & 0.335839 & \\
Linear & & 4.542448 & $R^{2}=0.9971$ \\
\hline
\end{tabular}

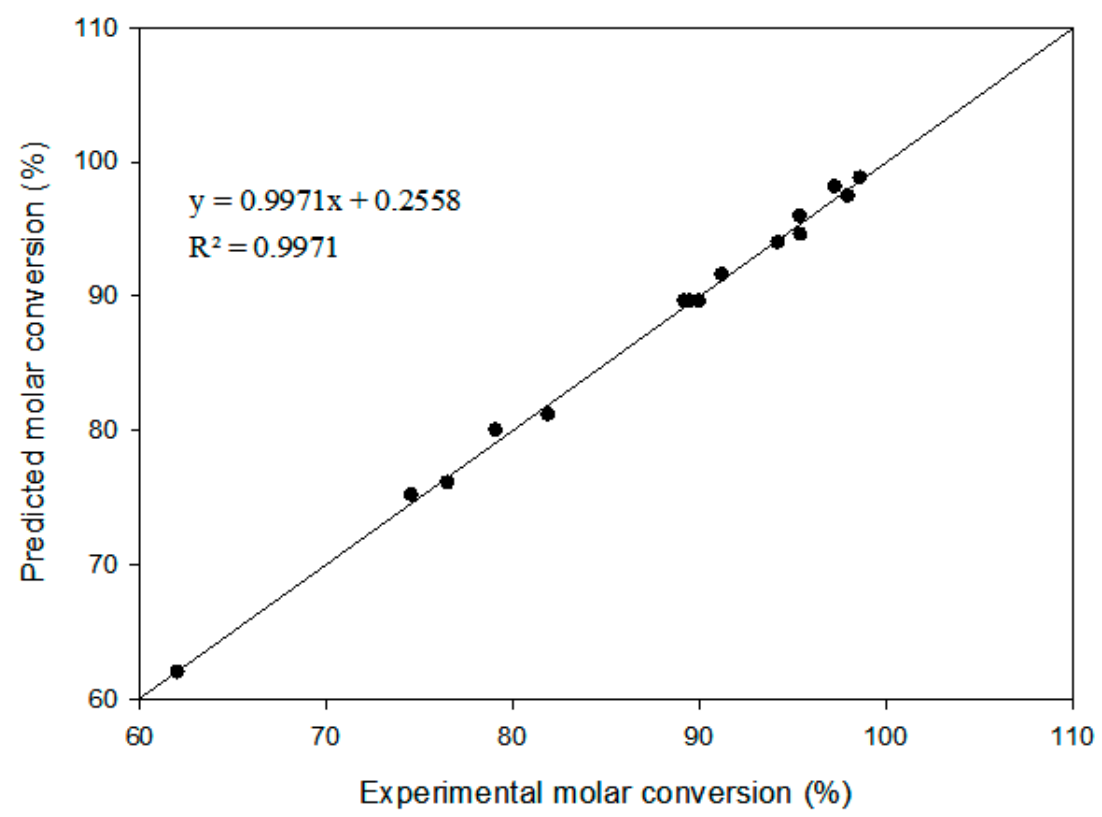

Figure 3. A linear relationship between the predicted and experimental molar conversion of 2-PEAC.

Table 3. Analysis of continuous synthesis variance of 2-PEAc in joint test ANOVA for substrate concentration pertaining to the response (initial rate).

\begin{tabular}{cccc}
\hline Factors & Degree of Freedom & Sum of Squares & Prob $>$ F \\
\hline Concentration of 2-PE $\left(\mathrm{X}_{1}\right)$ & 4 & 234.012890 & $<0.0001$ \\
Flow rate $\left(\mathrm{X}_{2}\right)$ & 4 & 191.319574 & $<0.0001$ \\
Temperature $\left(\mathrm{X}_{3}\right)$ & 4 & 7.255284 & 0.0213 \\
\hline
\end{tabular}

\subsection{Mutual Effect of Parameters}

As shown in Figure 4A, the response surface plots show the effect of the concentration of 2-PE and flow rate on the molar conversion of 2-PEAc catalyzed by Novozym ${ }^{\circledR} 435$ at $55{ }^{\circ} \mathrm{C}$. When the concentration of 2-PE decreased from 500 to $100 \mathrm{mM}$, the molar conversion increased by approximately $10 \%$ and $30 \%$ at flow rates of $1 \mathrm{~mL} \mathrm{~min}^{-1}$ and $5 \mathrm{~mL} \mathrm{~min}^{-1}$, respectively. The results indicated that the molar conversion increased as 2-PE concentration decreased and the flow rate increased. 

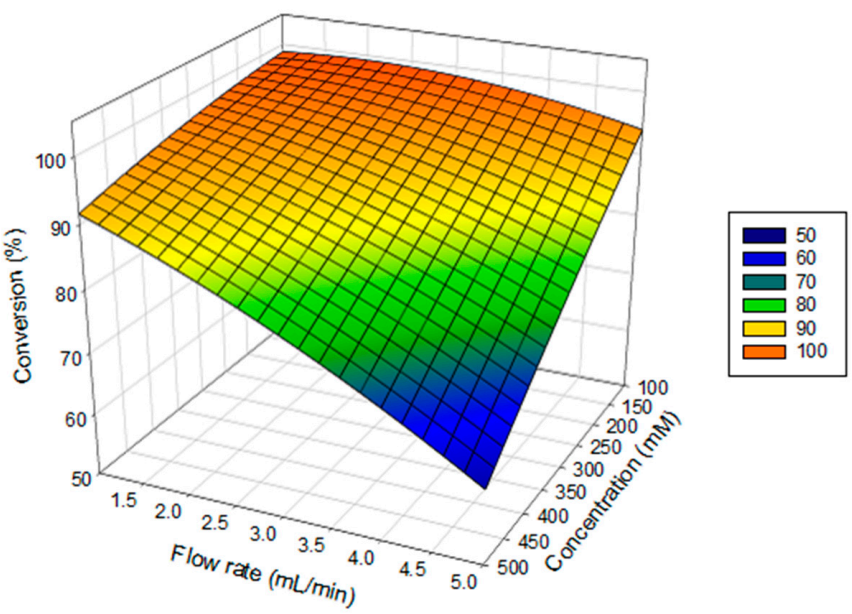

(A)
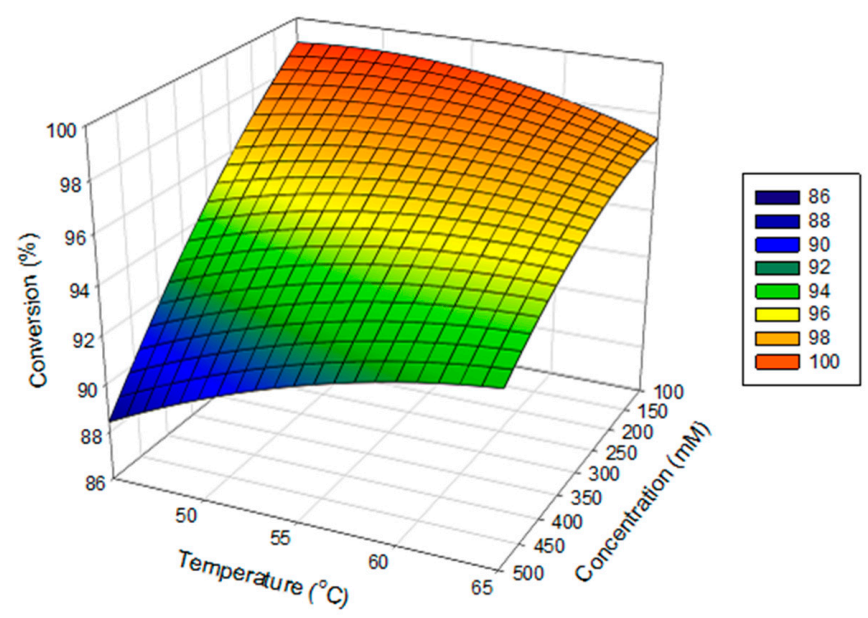

(B)
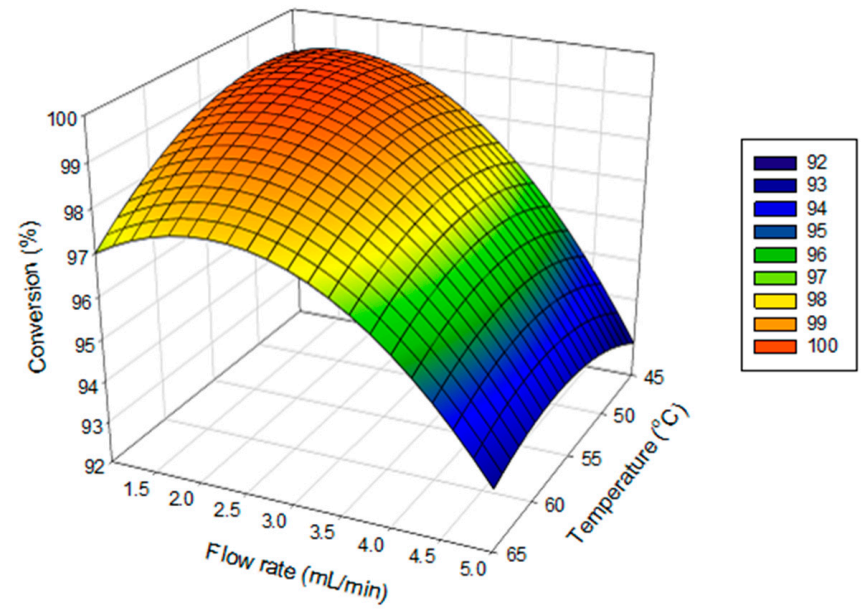

(C)

Figure 4. Response surface plots show the mutual effects of reaction (A) flow rate and concentration of 2-PE at a temperature of $55^{\circ} \mathrm{C}$; (B) temperature and concentration of 2-PE at a flow rate of $1 \mathrm{~mL} \mathrm{~min}^{-1}$; (C) flow rate and temperature at a 2-PE concentration of $100 \mathrm{Mm}$.

Figure $4 \mathrm{~B}$ shows the effects of concentration of 2-PE and reaction temperature on the molar conversion of 2-PEAc at $1 \mathrm{~mL} \mathrm{~min}{ }^{-1}$ flow rate, indicating that the higher molar conversion was 
observed depending on a decreased level of 2-PE concentration and an increased level of reaction temperature. Moreover, Figure $4 \mathrm{C}$ illustrates the effects of flow rate and reaction temperature on molar conversion of 2-PEAc at a fixed 2-PE concentration of $100 \mathrm{mM}$, indicating that the higher molar conversion was obtained by decreasing flow rate when reaction temperature increased from $45^{\circ} \mathrm{C}$ to $60^{\circ} \mathrm{C}$. By keeping each constant and examining a series of contour plots generated from the prediction model, Equation (1), the relationship between the reaction factors and response, can be better understood. From the joint test (Table 3), it was found that concentration of PE $\left(X_{1}\right)$ and flow rate $\left(X_{2}\right)$ were the most important variables for 2-PEAc synthesis $\left(p<0.0001\right.$, while the temperature $\left(X_{3}\right)$ has less effect on 2-PEAc synthesis $(p=0.0213)$, as compared to the concentration of PE and flow rate.

The similar results observed in contour plots are shown in Figure 5. At any given concentration of 2-PE from 100 to $500 \mathrm{mM}$, Figure $5 \mathrm{a}-\mathrm{c}$ indicated that a decrease both in flow rate and 2-PE concentration led to a higher molar conversion of 2-PEAc at different fixed reaction temperatures. The effects of varying concentrations of 2-PE and reaction temperature are shown in Figure $5 \mathrm{~d}-\mathrm{f}$. At any given flow rate from 1 to $5 \mathrm{~mL} \mathrm{~min}^{-1}$, a decrease in an adequate reaction temperature was effective for the molar conversion of 2-PEAc. The effects of different flow rates and the reaction temperatures are shown in Figure 5g-i. Reaction temperature has less effect on the molar conversion of 2-PEAc. In addition, Figure $5 \mathrm{~g}$ shows that a better molar conversion occurred at around $150 \mathrm{mM} 2-\mathrm{PE}, 3 \mathrm{~mL} \mathrm{~min}^{-1}$, and $55^{\circ} \mathrm{C}$ experimental conditions. It should be noted that in a continuous lipase catalytic system, the reduction in flow rate and substrate molecules would lead to an increase in molar conversion. This phenomenon may be that excess substrate is not easily reacted at a high concentration of 2-PE or flow rate, resulting in a decrease in molar conversion. Furthermore, the higher temperature had little effect on the conversion at $60{ }^{\circ} \mathrm{C}$, indicating that the temperature higher than $60^{\circ} \mathrm{C}$ may denature the enzyme and reduce the molar conversion.

\subsection{Attaining Optimization}

In this study, the optimal synthesis of 2-PEAc was determined by ridge max analysis, which calculated the maximum response when the radius increased from the original design center. As shown in Table 4, the ridge max analysis predicted that the maximum conversion was $100.22 \%$ at $62.07 \mathrm{mM}$ 2-PE and $2.75 \mathrm{~mL} \mathrm{~min}^{-1}$ flow rate, respectively. The validity of the prediction model is tested by conducting experiments under the best conditions for prediction. According to the statistics of the ridge maximum results, the maximum molar conversion rate was $99.01 \pm 0.09 \%$, indicating that the observed values are consistent with the predicted values from Equation (1). Presently, the continuous-flow bioreactor is suitable for maximizing the reaction efficiency, minimizing the demand for power and volume, and fully mixing the enzyme and substrate to attend a faster reaction rate. Obviously, from the statistical analysis results of RSM and ridge max, the optimal reaction conditions of this study include higher molar conversion by continuous lipase-catalyzed synthesis system.

Table 4. The estimated ridge of maximum response for variable production rate.

\begin{tabular}{cccccc}
\hline \multirow{2}{*}{$\begin{array}{c}\text { Coded } \\
\text { Radius }\end{array}$} & \multirow{2}{*}{$\begin{array}{c}\text { Estimated } \\
\text { Response }\end{array}$} & \multirow{2}{*}{$\begin{array}{l}\text { Observed } \\
\text { Response }\end{array}$} & \multicolumn{3}{c}{ Uncoded Factor Values } \\
\cline { 4 - 6 } & $\mathbf{( \% )}$ & $(\mathbf{\%})$ & $\begin{array}{c}\mathbf{X}_{\mathbf{1}} \\
(\mathbf{m M})\end{array}$ & $\begin{array}{c}\mathbf{X}_{\mathbf{2}} \\
(\mathbf{m L} / \mathbf{m i n})\end{array}$ & $\begin{array}{c}\mathbf{X}_{\mathbf{3}} \\
\left({ }^{\circ} \mathbf{C}\right)\end{array}$ \\
\hline 0.0 & $89.59 \pm 0.55$ & $89.59 \pm 0.41$ & 300.00 & 3.00 & 55.00 \\
0.2 & $92.02 \pm 0.54$ & $91.23 \pm 0.30$ & 269.05 & 2.75 & 55.17 \\
0.4 & $94.11 \pm 0.53$ & $92.65 \pm 0.22$ & 235.09 & 2.54 & 55.25 \\
0.6 & $95.87 \pm 0.51$ & $95.12 \pm 0.14$ & 196.17 & 2.40 & 55.18 \\
0.7 & $96.65 \pm 0.51$ & $95.80 \pm 0.09$ & 174.46 & 2.38 & 55.07 \\
0.8 & $97.39 \pm 0.52$ & $97.19 \pm 0.35$ & 151.65 & 2.40 & 54.90 \\
1.0 & $98.80 \pm 0.59$ & $98.74 \pm 0.04$ & 105.61 & 2.54 & 54.49 \\
1.2 & $100.22 \pm 0.73$ & $99.01 \pm 0.09$ & 62.07 & 2.75 & 54.03 \\
\hline
\end{tabular}


(a) $45^{\circ} \mathrm{C}$

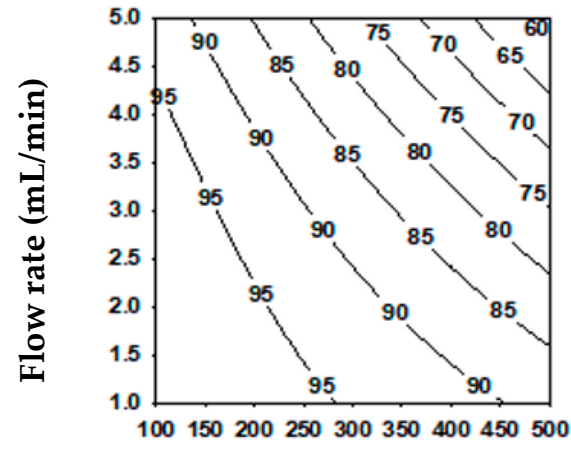

(d) $1 \mathrm{~mL} / \mathrm{min}$

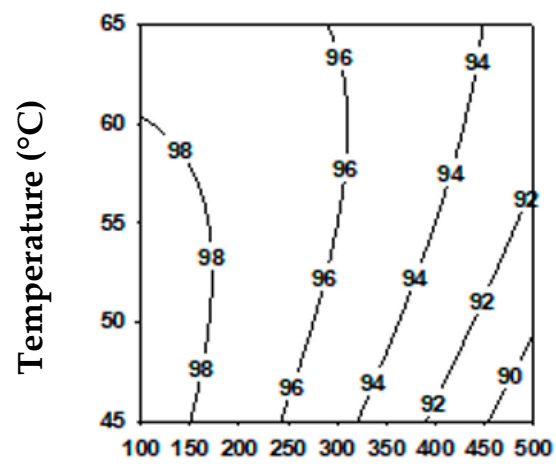

(g) $100 \mathrm{nM}$

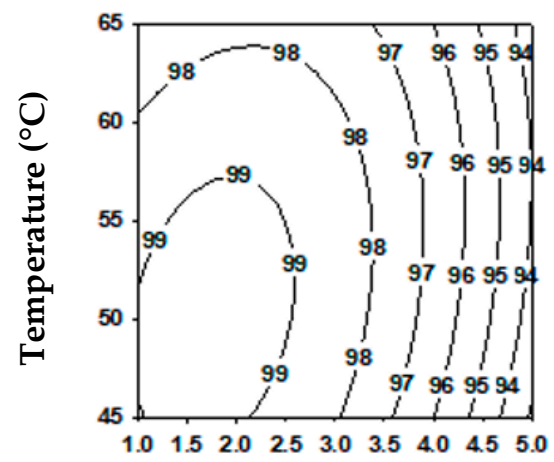

Temperature $\left({ }^{\circ} \mathrm{C}\right)$

(b) $55^{\circ} \mathrm{C}$

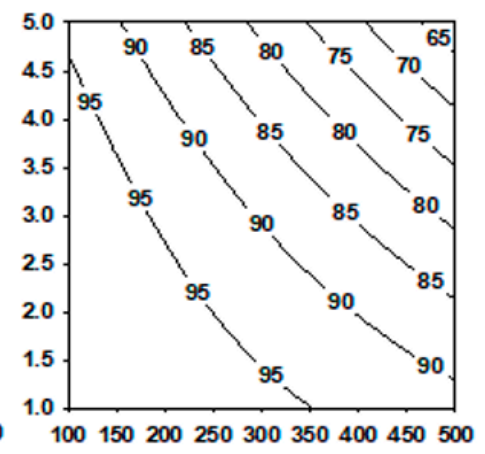

(c) $65^{\circ} \mathrm{C}$

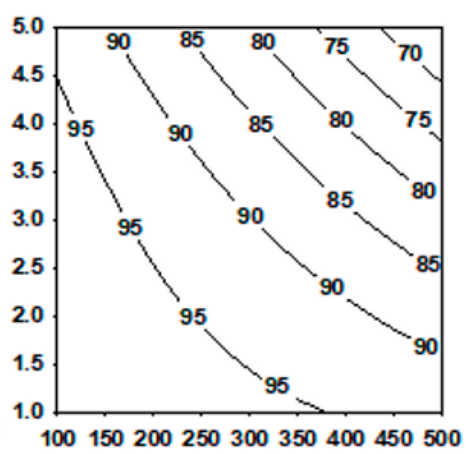

Flow rate $(\mathrm{mL} / \mathrm{min})$

(e) $3 \mathrm{~mL} / \mathrm{min}$

(f) $5 \mathrm{~mL} / \mathrm{min}$
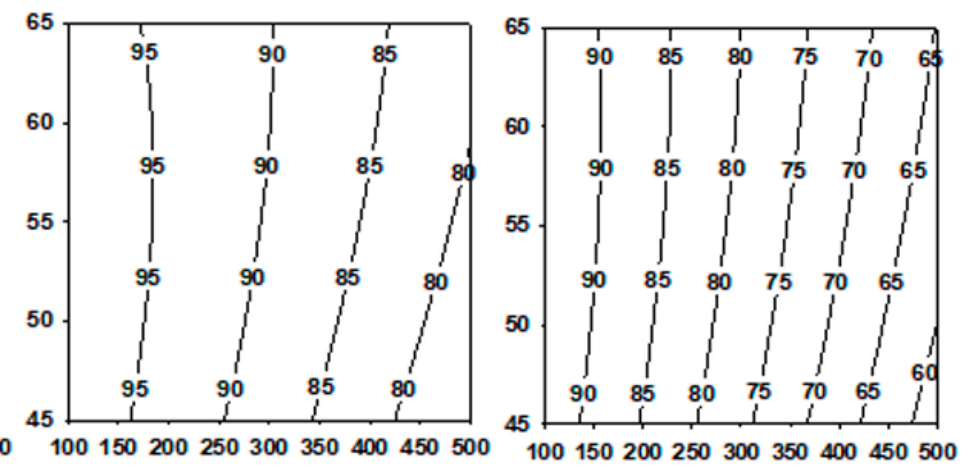

Concentration (nM)

(h) $300 \mathrm{nM}$

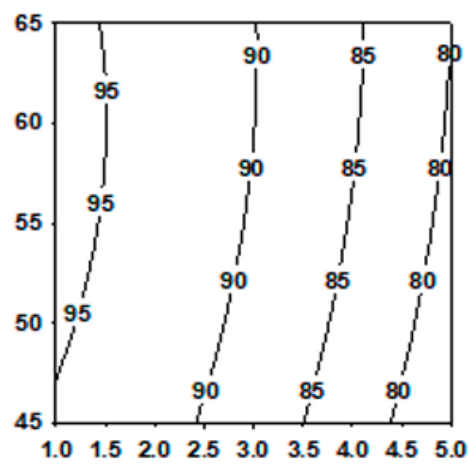

(i) $500 \mathrm{nM}$

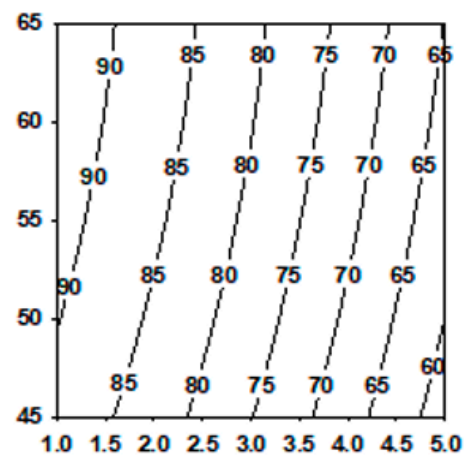

Figure 5. Contour plots show response behavior with varying concentration of 2-PE and flow rate at (a) $45^{\circ} \mathrm{C}$, (b) $55^{\circ} \mathrm{C}$ and (c) $65^{\circ} \mathrm{C}$; concentration of 2-PE and temperature at flow rate (d) $1 \mathrm{~mL} \mathrm{~min}^{-1}$, (e) $3 \mathrm{~mL} \mathrm{~min}^{-1}$ and (f) $5 \mathrm{~mL} \mathrm{~min}^{-1}$; flow rate and temperature at (g) $100 \mathrm{mM}$, (h) $300 \mathrm{mM}$ and (i) 500 $\mathrm{mM} 2-\mathrm{PE}$; numbers on contours denote molar conversion of 2-PEAc (\%) at given reaction conditions.

\subsection{Operational Stability}

The purpose of this part of the experiment was to determine the stability of this enzyme for long-time operation. Since the reaction produces a by-product of ethanol in the batch reactor system leading to enzyme inhibition, the inhibition would make lipase less active. The enzymatic synthesis of pentyl oleate with immobilized lipase was inhibited by a high concentration of 1-penthanol [38]. This inhibition effect has been found in reactions among butyric and lauric acid with ethanol $[39,40]$. Therefore, the stability of the enzyme in the batch reactor will not be better than that in the continuous packed bed reactor, because the product in the packed bed reactor is continuously removed from 
the column, which can avoid the excessive concentration of by-product ethanol causing the enzyme inhibition. The Novozym ${ }^{\circledR} 435$ in the continuous packed bed is operated for 3 days under the conditions of a 2-PE concentration of $257.44 \mathrm{mM}$, a flow rate of $1.049 \mathrm{~mL} \mathrm{~min}^{-1}$, and a reaction temperature of $55.59{ }^{\circ} \mathrm{C}$. The experimental results are shown in Figure 6. After 3 days of operation, the molar conversion is still $94 \%$, and there is no tendency to decline. The experimental results are similar to those reported by Royon et al., who used packed bed reactors to investigate the production and stability of Novozym ${ }^{\circledR} 435$ catalyzed cotton seed oil to produce biodiesel. After operation for 20 days, the yield remained at 95\% [41]. Halim et al. used a packed bed reactor with immobilized lipase to produce biodiesel from waste palm oil with transesterification. After $120 \mathrm{~h}$ of operation, the production of fatty acid methyl esters was $79 \%$, and there was no obvious decline [42]. Chang et al. discussed the use of Novozym ${ }^{\circledR} 435$ as the catalyst for the production of biodiesel in the continuous packed bed reactor. After 7.5 days of operation, there was still a $75 \%$ yield with no tendency to decline [43]. Our results show that Novozym ${ }^{\circledR} 435$ is suitable for the continuous packed bed reactor to catalyze the synthesis of 2-PEAc. Compared to the batch reactor, the stability of long-term operation can be attributed to the by-product ethanol not accumulating in the continuous packed bed reactor.

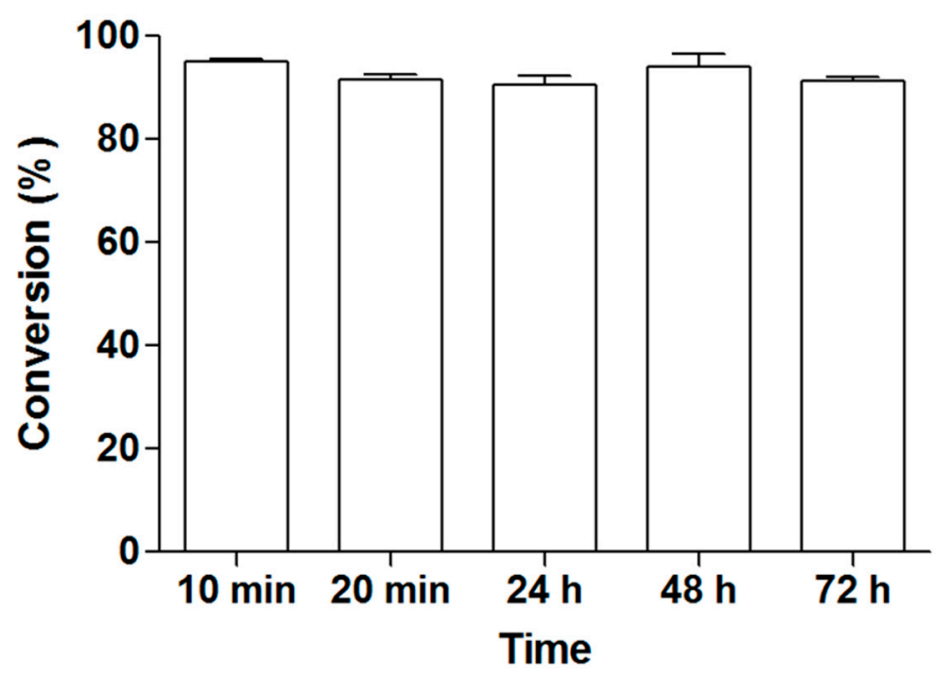

Figure 6. Continuous packed bed reactor with Novozym ${ }^{\circledR} 435$ to synthesize 2-PEAc. The reaction was carried out for 3 days at an enzyme amount of 10,000 propyl laurate units (PLU), a 2-PE concentration of $257 \mathrm{mM}$, a flow rate of $1 \mathrm{~mL} \mathrm{~min}^{-1}$ and reaction temperature of $56^{\circ} \mathrm{C}$.

Therefore, the continuous packed bed reactor is very suitable for the industrial mass production of rose flavoured 2-PEAc.

\section{Materials and Methods}

\subsection{Materials}

Immobilized lipase Novozym ${ }^{\circledR} 435$ (10,000 propyl laurate units, PLU, $\left.\mathrm{g}^{-1}\right)$ from Candida antarctica B (EC 3.1.1.3) was supported on a macroporous acrylic resin. 2-PE, 2-PEAc, and EA were purchased from Sigma Chemical Co. (St Louis, MO, USA). Molecular sieve $4 \AA$ was obtained from Davison Chemical (Baltimore, MD, USA). All chemicals employed were of analytical reagent grade.

\subsection{Continuous Lipase-Catalyzed Synthesis of 2-Phenylethyl Acetate (2-PEAc)}

All materials were dehydrated through a $4 \AA$ molecular sieve overnight. Novozym ${ }^{\circledR} 435$ was used as a biocatalyst for the esterification of 2-PE and EA (Figure 1). Before reaction, different concentrations of 2-PE (100-500 mmol L-1) in EA were thoroughly mixed in a feeding flask. The reaction was implemented in a stainless-steel tube packed-bed reactor. The reactor is $25 \mathrm{~cm}$ in length with an inner 
diameter of $0.46 \mathrm{~cm}$ and contains $1 \mathrm{~g}$ of Novozym ${ }^{\circledR} 435$. The reaction mixture was pumped continuously into the reactor under designed conditions. The flow rates $\left(1-5 \mathrm{~mL} \mathrm{~min}^{-1}\right)$ were controlled by a Hitachi L-7100 Quaternary Gradient Pump (Hitachi, Tokyo, Japan). The diagram of the stainless-steel tube packed-bed reactor is shown in Figure 7. Based on the reactor design in this study, the reactor is a plug flow model. Assuming that there is no boundary layer near the inner wall of the tube, the mean residence time could be evaluated from 4.15 to $0.83 \mathrm{~min}$ at a flow rate of 1 to $5 \mathrm{~mL} \mathrm{~min}{ }^{-1}$.

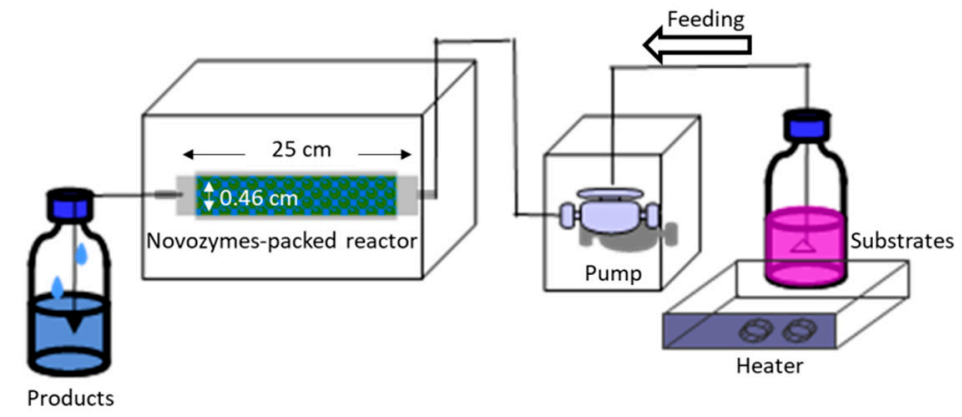

Figure 7. The diagram of the Novozym ${ }^{\circledR} 435$ packed-bed bioreactor.

\subsection{Experimental Design}

In this study, the three-level-three-factor Box-Behnken design was employed, and 15 experiments were carried out in a continuous packed-bed reactor and a solvent-free system. The experimental variables were 2-phenethyl alcohol (2-PE) concentration $\left(100-500 \mathrm{mmol} \mathrm{L}^{-1}\right)$, mixture flow rate $\left(1-5 \mathrm{~mL} \mathrm{~min}^{-1}\right)$ and reaction temperature $\left(45-65^{\circ} \mathrm{C}\right)$, as shown in Table 1.

\subsection{Quantitation of 2-PEAc}

After the synthesis reaction, 2-PEAc in the reaction mixture was quantitated by injecting a $1 \mu \mathrm{L}$ aliquot of the mixture into an Agilent 7890A gas chromatography (Agilent Technologies, Santa Clara, CA, USA) equipped with a flame ionization detector (FID) and MTX-65 TG fused silica capillary column ( $30 \mathrm{~m} \times 0.25 \mathrm{~mm}$ i.d., film thickness $0.1 \mu \mathrm{m}$; Restek Corp., Bellefonte, PA, USA). The injector and FID temperatures were set to 230 and $250{ }^{\circ} \mathrm{C}$. The oven temperature was maintained at $80^{\circ} \mathrm{C}$ for $2 \mathrm{~min}$, raised to $100^{\circ} \mathrm{C}$ at a rate of $20^{\circ} \mathrm{C} \mathrm{min}^{-1}$ for $3 \mathrm{~min}$, and finally raised to $230^{\circ} \mathrm{C}$ at a rate of $50^{\circ} \mathrm{C} \mathrm{min}^{-1}$, then held for $1.5 \mathrm{~min}$. Nitrogen is a carrier gas with a constant flow rate of $3.5 \mathrm{~mL} \mathrm{~min}{ }^{-1}$. The molar conversion (\%) is defined as (the number of moles of 2-PEAc produced per initial 2-PE mole added) $\times 100$.

\subsection{Statistical Analysis}

The experimental data (Table 1) were analyzed by response surface regression (RSREG) procedure of SAS (SAS Institute, Cary, NC, USA) to fit the second-order polynomial equation (Equation (2)).

$$
\gamma=\beta_{k 0}+\sum_{i=1}^{3} \beta_{i} x_{i}+\sum_{i=1}^{3} \beta_{i i} x_{i}^{2}+\sum_{i=1}^{2} \sum_{j=i+1}^{3} \beta_{i j} x_{i} x_{j}
$$

where $\gamma$ is the response (molar conversion \%), $\beta_{k 0}$ is a constant, $\beta_{k i}, \beta_{k i i}$ and $\beta_{k i j}$ are coefficients and $x_{i}$ and $x_{j}$ are the non-coded independent variables. The ridge-max option was used to calculate the estimated ridge of the maximum response when the radius increases from the original design center.

\section{Conclusions}

The continuous Novozyme ${ }^{\circledR} 435$-catalyzed synthesis of 2-PEAc in the solvent-free system was studied. The synthesis of 2-PEAc was optimized by the Box-Behnken design and RSM method, and the experimental design method was suitable for the optimization of operating conditions. Productivity was significantly affected by 2-PE concentration and flow rate, and the maximum conversion was $99.01 \pm 0.09 \%$ at $62.07 \mathrm{mM} 2-\mathrm{PE}$ and $2.75 \mathrm{~mL} \mathrm{~min}^{-1}$ flow rate, and $54.03{ }^{\circ} \mathrm{C}$, respectively. Finally, this 
solvent-free esterification system can be applied to the environmentally friendly production of natural flavour compounds, such as rose aromatic esters.

Author Contributions: Conceptualization, C.-J.S. and C.-H.K.; investigation, Y.-M.C.; data curation, S.-M.H. and Y.-M.C.; writing-original draft preparation, S.-M.H., H.-Y.H. and C.-H.K.; writing-review and editing, C.-J.S. and C.-H.K. All authors have read and agreed to the published version of the manuscript.

Funding: The authors are very grateful to the Ministry of Science and Technology of Taiwan, ROC for supporting this research (Grants No. 107-2320-B-005 -012-MY3).

Conflicts of Interest: There is no conflict of interest regarding the publication of this article.

\section{References}

1. McGinty, D.; Vitale, D.; Letizia, C.S.; Api, A.M. Fragrance material review on phenethyl acetate. Food Chem. Toxicol. 2012, 50, S491-S497. [CrossRef] [PubMed]

2. Sá, A.G.A.; Meneses, A.C.D.; Araújo, P.H.H.D.; Oliveira, D.D. A review on enzymatic synthesis of aromatic esters used as flavor ingredients for food, cosmetics and pharmaceuticals industries. Trends Food Sci. Technol. 2017, 69, 95-105. [CrossRef]

3. Bayout, I.; Bouzemi, N.; Guo, N.; Mao, X.; Serra, S.; Riva, S.; Secundo, F. Natural flavor ester synthesis catalyzed by lipases. Flavour Fragr. J. 2020, 35, 209-218. [CrossRef]

4. Shalit, M.; Guterman, I.; Volpin, H.; Bar, E.; Tamari, T.; Menda, N.; Adam, Z.; Zamir, D.; Vainstein, A.; Weiss, D.; et al. Volatile ester formation in roses. Identification of an acetyl-coenzyme A. Geraniol/Citronellol acetyltransferase in developing rose petals. Plant Physiol. 2003, 131, 1868-1876. [CrossRef]

5. Guterman, I.; Masci, T.; Chen, X.; Negre, F.; Pichersky, E.; Dudareva, N.; Weiss, D.; Vainstein, A. Generation of phenylpropanoid pathway-derived volatiles in transgenic plants: Rose alcohol acetyltransferase produces phenylethyl acetate and benzyl acetate in petunia flowers. Plant Mol. Biol. 2006, 60, 555-563. [CrossRef]

6. Hirata, H.; Ohnishi, T.; Watanabe, N. Biosynthesis of floral scent 2-phenylethanol in rose flowers. Biosci. Biotechnol. Biochem. 2016, 80, 1865-1873. [CrossRef]

7. Arora, P.K. Microbial Technology for the Welfare of Society; Springer: Singapore, 2019.

8. Martinez-Avila, O.; Sanchez, A.; Font, X.; Barrena, R. Bioprocesses for 2-phenylethanol and 2-phenylethyl acetate production: Current state and perspectives. Appl. Microbiol. Biotechnol. 2018, 102, 9991-10004. [CrossRef]

9. Adler, P.; Hugen, T.; Wiewiora, M.; Kunz, B. Modeling of an integrated fermentation/membrane extraction process for the production of 2-phenylethanol and 2-phenylethylacetate. Enzyme Microb. Technol. 2011, 48, 285-292. [CrossRef]

10. Khan, N.R.; Rathod, V.K. Enzyme catalyzed synthesis of cosmetic esters and its intensification: A review. Process Biochem. 2014, 50, 1793-1806. [CrossRef]

11. Majetic, C.J.; Raguso, R.A.; Ashman, T.L. The impact of biochemistry vs. population membership on floral scent profiles in colour polymorphic Hesperis matronalis. Ann. Bot. 2008, 102, 911-922. [CrossRef]

12. Białecka-Florjańczyk, E.; Krzyczkowska, J.; Stolarzewicz, I.; Kapturowska, A. Synthesis of 2-phenylethyl acetate in the presence of Yarrowia lipolytica KKP 379 biomass. J. Mol. Catal. B Enzym. 2012, 74, 241-245. [CrossRef]

13. Guo, D.; Zhang, L.; Pan, H.; Li, X.; Guo, D.; Zhang, L.; Pan, H.; Li, X. Metabolic engineering of Escherichia coli for production of 2-phenylethylacetate from L-phenylalanine. MicrobiologyOpen 2017, 6, e00486. [CrossRef] [PubMed]

14. Zhang, B.; Xu, D.; Duan, C.; Yan, G. Synergistic effect enhances 2-phenylethyl acetate production in the mixed fermentation of Hanseniaspora vineae and Saccharomyces cerevisiae. Process Biochem. 2020, 90, 44-49. [CrossRef]

15. Xavier Malcata, F.; Reyes, H.R.; Garcia, H.S.; Hill, C.G.; Amundson, C.H. Immobilized lipase reactors for modification of fats and oils-A review. J. Am. Oil Chem. Soc. 1990, 67, 890-910. [CrossRef]

16. Fomuso, L.B.; Akoh, C.C. Lipase-catalyzed acidolysis of olive oil and caprylic acid in a bench-scale packed bed bioreactor. Food Res. Int. 2002, 35, 15-21. [CrossRef]

17. Facin, B.R.; Melchiors, M.S.; Valério, A.; Oliveira, J.V.; Oliveira, D.D. Driving immobilized lipases as biocatalysts: 10 years state of the art and future prospects. Ind. Eng. Chem. Res. 2019, 58, 5358-5378. [CrossRef] 
18. Nielsen, N.S.; Yang, T.; Xu, X.; Jacobsen, C. Production and oxidative stability of a human milk fat substitute produced from lard by enzyme technology in a pilot packed-bed reactor. Food Chem. 2006, 94, 53-60. [CrossRef]

19. Mathpati, A.C.; Kalghatgi, S.G.; Mathpati, C.S.; Bhanage, B.M. Immobilized lipase catalyzed synthesis of n-amyl acetate: Parameter optimization, heterogeneous kinetics, continuous flow operation and reactor modeling. J. Chem. Technol. Biotechnol. 2018, 93, 2906-2916. [CrossRef]

20. Ye, R.; Hayes, D.G.; Burton, R.; Liu, A.; Harte, F.M.; Wang, Y. Solvent-free lipase-catalyzed synthesis of technical-grade sugar esters and evaluation of their physicochemical and bioactive properties. Catalysts 2016, 6, 78. [CrossRef]

21. Kuo, C.H.; Chen, H.H.; Chen, J.H.; Liu, Y.C.; Shieh, C.J. High yield of wax ester synthesized from cetyl alcohol and octanoic acid by lipozyme RMIM and Novozym 435. Int. J. Mol. Sci. 2012, 13, 11694-11704. [CrossRef]

22. Chojnacka, A.; Gładkowski, W. Production of structured phosphatidylcholine with high content of myristic acid by lipase-catalyzed acidolysis and interesterification. Catalysts 2018, 8, 281. [CrossRef]

23. Kim, K.H.; Lee, O.K.; Lee, E.Y. Nano-immobilized biocatalysts for biodiesel production from renewable and sustainable resources. Catalysts 2018, 8, 68.

24. Ortiz, C.; Ferreira, M.L.; Barbosa, O.; dos Santos, J.C.S.; Rodrigues, R.C.; Berenguer-Murcia, Á.; Briand, L.E.; Fernandez-Lafuente, R. Novozym 435: The "perfect" lipase immobilized biocatalyst? Catal. Sci. Technol. 2019, 9, 2380-2420. [CrossRef]

25. Ju, H.Y.; Yang, C.K.; Yen, Y.H.; Shieh, C.J. Continuous lipase-catalyzed synthesis of hexyl laurate in a packed-bed reactor: Optimization of the reaction conditions in a solvent-free system. J. Chem. Technol. Biotechnol. 2009, 84, 29-33. [CrossRef]

26. de Meneses, A.C.; Almeida Sá, A.G.; Lerin, L.A.; Corazza, M.L.; de Araújo, P.H.H.; Sayer, C.; de Oliveira, D. Benzyl butyrate esterification mediated by immobilized lipases: Evaluation of batch and fed-batch reactors to overcome lipase-acid deactivation. Process Biochem. 2019, 78, 50-57. [CrossRef]

27. Chapman, J.; Ismail, A.; Dinu, C. Industrial Applications of Enzymes: Recent Advances, Techniques, and Outlooks. Catalysts 2018, 8, 238. [CrossRef]

28. Ghamgui, H.; Karra-Chaabouni, M.; Gargouri, Y. 1-Butyl oleate synthesis by immobilized lipase from Rhizopus oryzae: A comparative study between n-hexane and solvent-free system. Enzyme Microb. Technol. 2004, 35, 355-363. [CrossRef]

29. Huang, S.M.; Wu, P.Y.; Chen, J.H.; Kuo, C.H.; Shieh, C.J. Developing a high-temperature solvent-free system for efficient biocatalysis of octyl ferulate. Catalysts 2018, 8, 338. [CrossRef]

30. Lee, C.C.; Chen, H.C.; Ju, H.Y.; Chen, J.H.; Kuo, C.H.; Chung, Y.L.; Liu, Y.C.; Shieh, C.J. Green and efficient production of octyl hydroxyphenylpropionate using an ultrasound-assisted packed-bed bioreactor. J. Ind. Microbiol. Biotechnol. 2012, 39, 655-660. [CrossRef]

31. Chen, H.C.; Kuo, C.H.; Twu, Y.K.; Chen, J.H.; Chang, C.M.J.; Liu, Y.C.; Shieh, C.J. A continuous ultrasound-assisted packed-bed bioreactor for the lipase-catalyzed synthesis of caffeic acid phenethyl ester. J. Chem. Technol. Biotechnol. 2011, 86, 1289-1294. [CrossRef]

32. Karra-Châabouni, M.; Ghamgui, H.; Bezzine, S.; Rekik, A.; Gargouri, Y. Production of flavour esters by immobilized Staphylococcus simulans lipase in a solvent-free system. Process Biochem. 2006, 41, 1692-1698. [CrossRef]

33. Kuo, C.H.; Huang, C.Y.; Lee, C.L.; Kuo, W.C.; Hsieh, S.L.; Shieh, C.J. Synthesis of DHA/EPA ethyl esters via lipase-catalyzed acidolysis using Novozym ${ }^{\circledR}$ 435: A kinetic study. Catalysts 2020, 10, 565. [CrossRef]

34. Rodriguez-Colinas, B.; Fernandez-Arrojo, L.; Santos-Moriano, P.; Ballesteros, A.O.; Plou, F.J. Continuous packed bed reactor with immobilized $\beta$-galactosidase for production of galactooligosaccharides (GOS). Catalysts 2016, 6, 189. [CrossRef]

35. Neifar, S.; Cervantes, F.V.; Bouanane-Darenfed, A.; BenHlima, H.; Ballesteros, A.O.; Plou, F.J.; Bejar, S. Immobilization of the glucose isomerase from Caldicoprobacter algeriensis on Sepabeads EC-HA and its efficient application in continuous high fructose syrup production using packed bed reactor. Food Chem. 2020, 309, 125710. [CrossRef] [PubMed]

36. Salvi, H.M.; Kamble, M.P.; Yadav, G.D. Synthesis of geraniol esters in a continuous-flow packed-bed reactor of immobilized lipase: Optimization of process parameters and kinetic modeling. Appl. Biochem. Biotechnol. 2018, 184, 630-643. [CrossRef] 
37. Sun, J.; Yu, B.; Curran, P.; Liu, S.Q. Lipase-catalysed transesterification of coconut oil with fusel alcohols in a solvent-free system. Food Chem. 2012, 134, 89-94. [CrossRef]

38. Cavallaro, V.; Tonetto, G.; Ferreira, M.L. Optimization of the enzymatic synthesis of pentyl oleate with lipase immobilized onto novel structured support. Fermentation 2019, 5, 48. [CrossRef]

39. Pires-Cabral, P.; Da Fonseca, M.; Ferreira-Dias, S. Synthesis of ethyl butyrate in organic media catalyzed by Candida rugosa lipase immobilized in polyurethane foams: A kinetic study. Biochem. Eng. J. 2009, 43, 327-332. [CrossRef]

40. Gawas, S.D.; Jadhav, S.V.; Rathod, V.K. Solvent free lipase catalysed synthesis of ethyl laurate: Optimization and kinetic studies. Appl. Biochem. Biotechnol. 2016, 180, 1428-1445. [CrossRef]

41. Royon, D.; Daz, M.; Ellenrieder, G.; Locatelli, S. Enzymatic production of biodiesel from cotton seed oil using t-butanol as a solvent. Bioresour. Technol. 2007, 98, 648-653. [CrossRef]

42. Halim, S.F.A.; Kamaruddin, A.H.; Fernando, W. Continuous biosynthesis of biodiesel from waste cooking palm oil in a packed bed reactor: Optimization using response surface methodology (RSM) and mass transfer studies. Bioresour. Technol. 2009, 100, 710-716. [CrossRef] [PubMed]

43. Chang, C.; Chen, J.H.; Chieh-ming, J.C.; Wu, T.T.; Shieh, C.J. Optimization of lipase-catalyzed biodiesel by isopropanolysis in a continuous packed-bed reactor using response surface methodology. New Biotechnol. 2009, 26, 187-192. [CrossRef] [PubMed]

(C) 2020 by the authors. Licensee MDPI, Basel, Switzerland. This article is an open access article distributed under the terms and conditions of the Creative Commons Attribution (CC BY) license (http://creativecommons.org/licenses/by/4.0/). 